
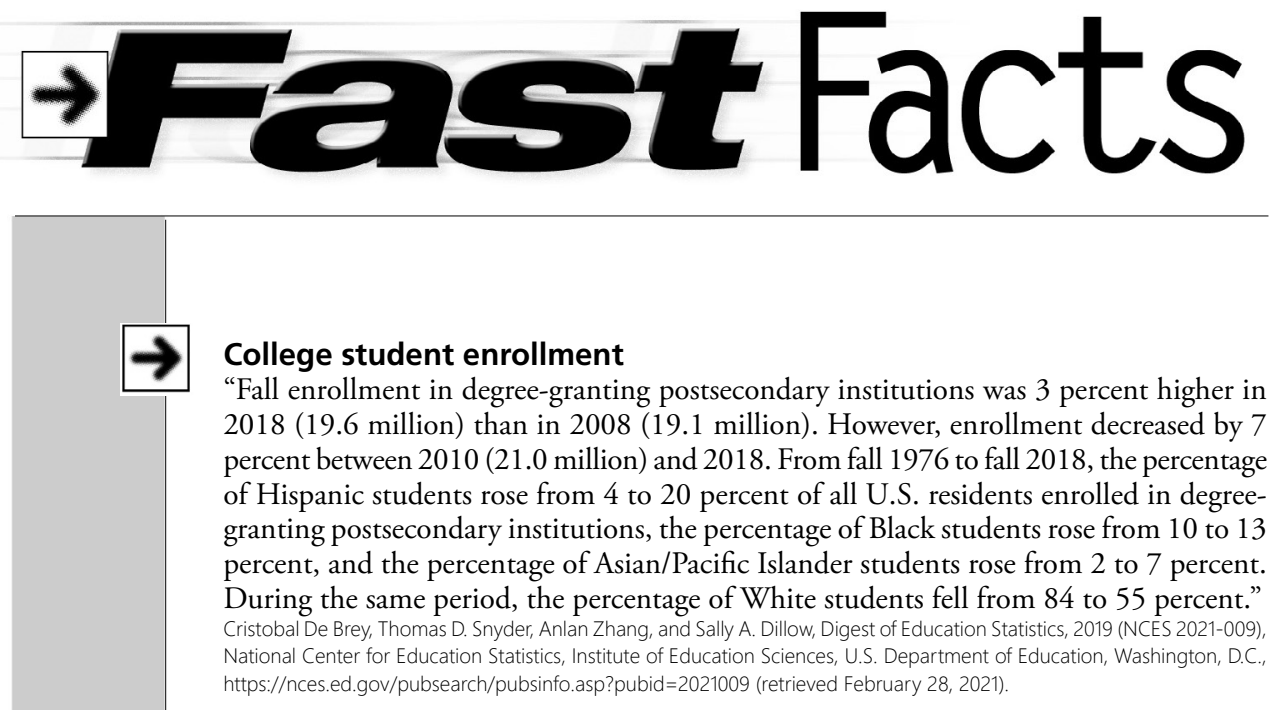

\title{
College student retention
}

"U.S. adults who have some college education but no degree and are not currently enrolled attribute their stopping classes to cost (25 percent), emotional stress (18 percent), and balancing family responsibilities (13 percent) as their top reasons for not completing their degree."

Jonathan Rothwell and Megan Brenan, "Students Continue to Weigh College Costs vs. Career Goals," Gallup, Inc., February 1, 2021, https://news.gallup.com/opinion/gallup/329120/students-continue-weigh-college-costs-career-goals.aspx (retrieved February 28, 2021).

\section{Social media users}

At the start of 2021, there were 4.20 billion active social media users worldwide. That equates to nearly 54 percent of the total global population. "The typical user has an account on more than 8 different social media platforms, and spends an average of close to $2 \frac{1}{2} 2$ hours using social media each day."

"Social Media Users," DataReportal-Global Digital Insights, January 2021, https://datareportal.com/social-media-users (retrieved March 1, 2021).

\section{In-person classes and COVID-19}

"Cases of COVID-19 increased 56 percent in U.S. counties with large colleges that hosted classes in person early this fall, according to new analyses from the CDC, published Jan. 8. By contrast, counties with large colleges that held classes remotely saw a nearly 18 percent drop in cases."

Rebecca Koenig, "Opening Campuses During Pandemic Sent Virus Cases Soaring in Communities, CDC Reports," EdSurge News, January 8, 2021, https://www.edsurge.com/news/2021-01-08-opening-campuses-during-pandemic-sent-virus-casessoaring-in-communities-cdc-reports (retrieved March 1, 2021).

\section{Online harassment}

"Roughly four-in-ten Americans have experienced online harassment, with half of this group citing politics as the reason they think they were targeted. Growing shares face more severe online abuse such as sexual harassment or stalking."

Emily Vogels, "The State of Online Harassment," Pew Research Center: Internet, Science \& Tech (blog), January 13, 2021, https://www.pewresearch.org/internet/2021/01/13/the-state-of-online-harassment (retrieved March 1, 2021).

Gary Pattillo is reference librarian at the University of North Carolina-Chapel Hill, e-mail: pattillo@email.unc.edu 